\title{
Research and Prediction of the Application of Multimedia Teaching Aid in Teaching Technical Education on the 2nd Level of Primary Schools
}

\author{
Ján STEBILA \\ Department of Technical and Technology, Faculty of Natural Science on Matej Bel University \\ Tajovského 40, 97401 Banská Bystrica SVK, Slovakia \\ e-mail: jan.stebila@umb.sk
}

Received: February 2011

\begin{abstract}
The purpose and the main aim of the pedagogic experiment were to practically verify the success of Multimedia Teaching Aid (MTA) in conditions of primary schools. We assumed that the use of our multimedia teaching aid in teaching technical education on the 2nd level of primary schools would significantly affect the level of knowledge of pupils from the issue of Road Safety Education (RSE), particularly in terms of performing, remembering, understanding, specific transfer and active learning of pupils.
\end{abstract}

Keywords: research, technical education, multimedia teaching aid, road safety education.

\section{Introduction}

Our long-term interest was, and still is, to teach pupils the elements of RSE. New innovative approaches allow us to use multimedia and computers in teaching (Kmet'ová, 2006). We tried to profit from our skills, knowledge and potential when searching and creating new effective teaching aids, which would fully replace the momentary deficit of them for the issue, and make the education more effective. Streamlining of teaching is a very difficult and long process and it cannot be solved comprehensively. When creating new multimedia teaching aid, we focused mainly on RSE issues where computers are used as means for teacher's work, but also for pupils - traffic participants. The issues are, in particular, skills to use a bicycle in traffic safely, basis of its maintenance and repair, traffic rules in terms of a cyclist, traffic signs, etc. Handling of these applications is the basic "equipment" of today's human society.

\section{Multimedia Teaching Aid for RSE}

The core of MTA is specially made of presentations and teaching text stored in the form of CDs. MTA accepts the current situation of information technology and pedagogicalpsychological processes. When we were creating it, the bases were our skills, experience, and knowledge in the field of RSE, multimedia production, psychology and didactics of technical subjects (Krišst'ák and Gajtanská, 2010). 
The teaching aid presents a new subject matter, procedures and solutions of problem tasks in the field of RSE to students. Initially, it requires an intensive work with a computer and it is associated with a certain risk that is always present when computers are used in teaching. Teaching through MTA brings much more pleasure from teaching the subject for teachers as well as learning for students. The effectiveness of the educational process exceeds traditional teaching methods. MTA helps pupils to achieve self-reliance, it encourages them to learn actively, it teaches them how to search and use information needed for their independent movement in traffic. It promotes activity and responsibility. Through MTA pupils learn how to discover, solve problems, experiment, and ask questions on this issue (Stebila, 2010; Kučerka, 2009).

A teacher acts as a consultant and organizer when using the aid during the lesson. He or she selects a subject matter based on the needs and interests of pupils. He or she supports the open communication, solving, thinking, or ideas and leads pupils to make decisions on their own. The teacher requires from the pupils to evaluate their activities and express their opinions.

If pupils are led to any practical or intellectual skills, they have certain needs. These needs occur when pupils learn things that require a corrected practice.

If the education is supposed to be effective, the needs of the pupil must be met in the cognitive as well as in the affective area.

MTA is designed for MS Windows. The program is able to operate in the operating systems MS-DOS and MS Windows. If we want to use all the options, it is necessary to have a computer supporting the playback of various computer applications and respecting the system requirements mentioned above (CD-ROM or DVD-ROM drive, Adobe Reader, Windows, etc.). A mouse is a necessary element of control. To control the MTA program is very simple. Everything is controlled by the simple mouse clicking on various objects in the program. Running of the program from CD-ROM requires a free memory on the disk (c: disk requirements are reduced with more available memory). It is still possible to open the objects, if the mouse pointer has an arrow shape. Installing the program is not needed. MTA application runs right after you insert the media into the CD drive as Autorun - Bicycle.

Initial instructions are as follows:

- run the Windows operating system;

- insert the MTA CD into the CD drive and wait for the automatic run of Autorun Bicycle;

- the main menu of MTA appears.

Autorun - Bicycle (material on CD-ROM) is divided into the following main headings which include:

- a multimedia teaching aid - The Bicycle Program;

- the construction, basic repair and maintenance activities - PowerPoint presentation I;

- solving of traffic situations - PowerPoint Presentation II;

- publication in PDF - RSE (Bicycle - the basic means of transport).

The main menu is the base of the program. It is possible to choose the desired item by using the arrow pointer. The first item of the MTA offer is the Bicycle Program. It has 
the nature of interactive games with elements of Road Safety Education. It consists of the main MENU, which includes five main parts.

1) PROGRAM - brief information on orientation in the program is described here, pupils very quickly learn how to use the program.

2) ANIMATED CROSSROADS - ten selected traffic situations in 2D views. Various traffic situations are listed under numbers 1 to 10 , located at the top of the screen for a faster selection. The animation starts by „Start“. This is a simulation of a cyclist's ride, including solving traffic situations, applications of traffic regulations, and other interesting elements of the game (Fig. 1).

3) MEMORY GAME - a classical type of memory games. Randomly distributed cards are placed in the game field. The task is to look for a pair of identical pictures of road signs and their names. After choosing two cards, they are compared, and if they are the same, they remain visible. After the game, the cards are automatically mixed.

4) TEST - contains 28 questions on issues of road signs and traffic situations, where the response is supposed to be selected from the menu a, b, c. The number of the questions and correct answers is shown.

5) END - this section serves to complete the application. A single mouse click brings us back to Autorun - Bicycle.

Other files of MTA: The construction, basic repair and maintenance activities. Presentations in MS PowerPoint include solving traffic situations. In the first situation, there is a graphically presented bike (bicycle types, construction, main parts, construction junctions, repair works of various bicycle components, bicycle lighting system, adjusting of brakes, handlebars, seat, bicycle accessories, etc.). The next presentation indicates solutions to various traffic situations, especially crossroads with an interpretative text.

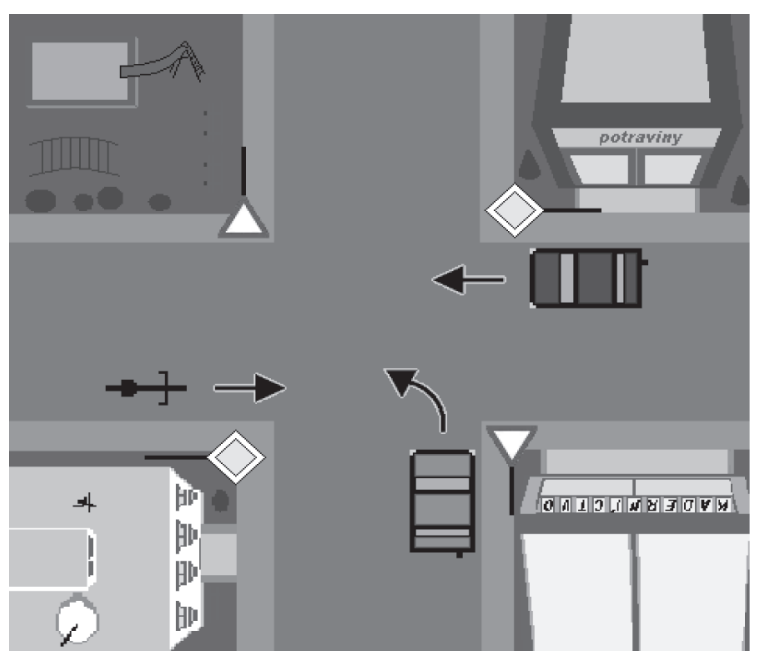

Fig. 1. Demonstration of a traffic situation from MTA. 
The presentations are closely connected to the content of the publication and they appropriately complete it.

The last file in the menu of MTA is a publication in .PDF - Road Safety Education. This teaching text is the first of its kind ever to be offered for exploitation of this issue at primary schools in Slovakia. Its aim is to provide the properly simple text with illustrations of RSE to teachers and pupils. The text should be used in an easy and enjoyable form for pupils. The emphasis is placed on motivation, diversity, and a comprehensive approach, but also on the proper implementation of traffic regulations. Specific information is given in the way to be specific, and in particular, based on real-life traffic is given in the text.

We tried to reconcile the content of the publication with the document The Concept of Road Safety Education at Primary Schools, issued by the Ministry of Education for implementation of RSE at primary schools. The mentioned suprasubjectival curricula and goals of RSE are based on the document (Stebila, 2010).

A bicycle, as a basic means of transport not only for pupils but also for adults, is becoming a part of everyday life. Another aim of the publication is connected with the correct use of the bicycle and especially with behavior in traffic. The content of the text is divided into clear teaching units dealing with all the important areas of RSE. We divided the whole issue into thirteen thematic units because of a simpler orientation and clarity.

The first unit Bicycle in Traffic gives us the initial information about how a bicycle must and can be equipped, if we want to enter the traffic with it. The second thematic unit Construction of the Bicycle provides the theoretical foundation of various bicycle parts. It explains the basic concepts and information about the basic bicycle parts (frame, wheels, wheel fork, brakes, seat, bicycle lights, etc.). Dismounting, Mounting and Maintenance of the Bicycle deals with the monthly and annual maintenance of the bicycle, and of course, the various service bicycle repairs too. The fourth unit Didactic Use of the Bicycle deals with issues of visual teaching aids, didactic use of the bicycle and examples of its use in practice. In the following five unites entitled Rules of Safe Cycling, Dangerous Places, Clear and Well-marked Cycling, We are Never Alone on the Road, and We Pass Through Crossroads traffic rules relating to the cyclist are the most important. In these thematic units, traffic rules are elaborated in terms of cyclists as well as different traffic situations and their solutions. They are accompanied by illustrative drawings that complete the learning text in an amusing way. The thematic unit entitled Traffic Accident and its Solution is dedicated to the cyclist drawbacks as the most vulnerable road user. A brief description of how to call and proceed with the first aid accompanied by illustrative drawings will help teachers to present this issue. The eleventh unit in order, Team Games and Competitions, deals with a test, artistic and slalom competitions, which can be used at schools for enriching the teaching. It is possible to use a school yard, school playground, gym, and in the limited case also a large hallway. The twelfth thematic unit is focused on Methods, Forms and Means of Road Safety Education. The last unit Children's Traffic Playgrounds deals with the current issue of CTP. It discusses the types and equipment of CTP, the organization of training, and its staff.

We tried to write the text in a simple and clear way. Whether the issues contained in each unit are adopted by pupils, it will be shown after taking the tests attached at the end 
of every chapter with the correct answers. The publication also focuses on road signs and various traffic situations in which a cyclist may occur. It is essential for cyclists to learn how to solve the traffic situation properly, and how to give the first aid in case of a traffic accident. The information and recommendations for improving the safety during cycling are equally important. When teaching the issue, the teacher can use various collective games and competitions, which are described in the publication, and which can be motivating for other games and competitions (Kmet'ová, 2006).

Various issues affect all areas of RSE in a complex way. A significant part of the publication is made of appendix. We pay attention to traffic signs, traffic facilities and light signals in five appendix on nineteen pages marked as Appendix A to Appendix E.

We consider the processing of the issue as the basis, which teachers should be particularly aware of, and in appropriately chosen way of didactics, pupils too. We cannot consider the processing of the issue to be completed. It represents the minimum literacy in this area, which should be acquired by pupils. When properly acquired practical skills and habits of driving the basic vehicle in traffic are used, it gives the assumption that the cyclists will be disciplined on the road and they will prevent traffic accidents because of their right behavior (Stebila, 2009; Žáčok, 2010; Hockicko, 2010).

\section{Recommendations for the Use of Multimedia Teaching Aid}

It is necessary to mention a few tips and recommendations on how to use the teaching aid it properly:

1) When using MTA, it is necessary to provide a teacher who mastered traffic rules except for technical and technological knowledge and skills (is a holder of a driving license, knows the legislation, and is in contact with the coordinator for RSE, etc.).

2) The teacher should, according to his or her teaching experience, know the knowledge and skills of pupils in the class, where he or she will use MTA during the lesson. The teacher should also be capable to determine the level of the chosen issues for individual pupils in class and he or she ought to know how long they will solve the tasks.

3) Before the first lesson, the teacher ought to answer the question: Do I want pupils to help each other or should they discuss all the uncertainties with me? If the teacher wants pupils to communicate with each other about problems, he or she should allow them to openly debate the issue and solve problems together.

4) Before the first lesson, the teacher should carefully describe how to work with MTA to pupils. He or she should thoroughly explain what to do, show the needed solution of the problem with the reasons why he or she proceeds in the chosen way. The teacher should try to motivate pupils and make it interesting for them.

5) The key for the success throughout the course is to familiarize pupils with the proper use and manipulation of MTA. If this is managed and it seems that everything is clear, they can start to work.

6) Pupils choose the main menu of MTA and choose its parts according to the teacher's instructions. These parts include the subject mater to the theme of RSE, 
which is discussed at the given time. This is learning in a funny way through presentations and games which should provoke a sense of responsibility of pupils. Through the well-arranged menu of the teaching aid, pupils gradually get from the teaching text, which describes the basic rules of behaving in traffic in the view of a cyclist. Through presentations, pupils become familiar with the basic equipment of a bicycle, basic maintenance and repairs, road signs and traffic situations, and they get to the testing of the acquired knowledge.

7) The teacher checks the work of pupils. The initiative checking of the right use of MTA is very important and it usually must take place before the teacher begins to deal with potential problems of individuals. The check allows the normal error correction and assessment of the work time, it provides a positive feedback to pupils and at the same time, it motivates them and adds self-reliance. If the teacher expresses criticism, praises positively and enough, then the pupils will enjoy his or her attention and they will be motivated.

8) In terms of optimal performance of pupils, it is appropriate when the teacher checks the work of each pupil, although it is very difficult in numerous classes.

9) The role of the teacher is active in the use of MTA. It does not include only the initial interpretation of what will be discussed on the particulary day, answers to questions and evaluation of results. In our case, the teacher must become a manager of the work, and especially helper and organizer of the lesson.

10) The tasks given by the teacher must be clear and understandable for the pupils. The teacher must observe the class even when moving among students or helping individuals. He or she should always try to have such a place, from which he or she will see the majority of the class. His or her attention will discourage potential candidates to the disturbance.

11) Some teachers often solve problems of their pupils in a wrong way. The teacher solves the problem instead of the pupils. It is much more effective when pupils are lead to know what the problem is, and then solve it on their own. They should assess their own performance, identify problems and solve them independently.

12) If the teacher wants to assess whether or not the lesson was successful and what could be improved in the future, he or she should take notes and record the observation during the lesson.

13) In the final parts of lessons, in the part of creativity and improving, it is recommended to solve the test within the verification of knowledge and feedback. The test contains questions on road signs, which are taught through memory games and traffic situations which were learnt while watching 2D animations. The teacher thus gains quick information on the achievement of the objectives of the lesson.

14) We should not overlook the evaluation of pupils' results. We have to have enough time for it, because it is one of the most important elements of teaching. It is important that pupils discuss the results with the teacher. It could be a discussion after the lesson.

15) The teacher should not unnecessarily prolong the lesson, although it often happens that he or she forgets about the limited time of the lesson when working on a computer. 


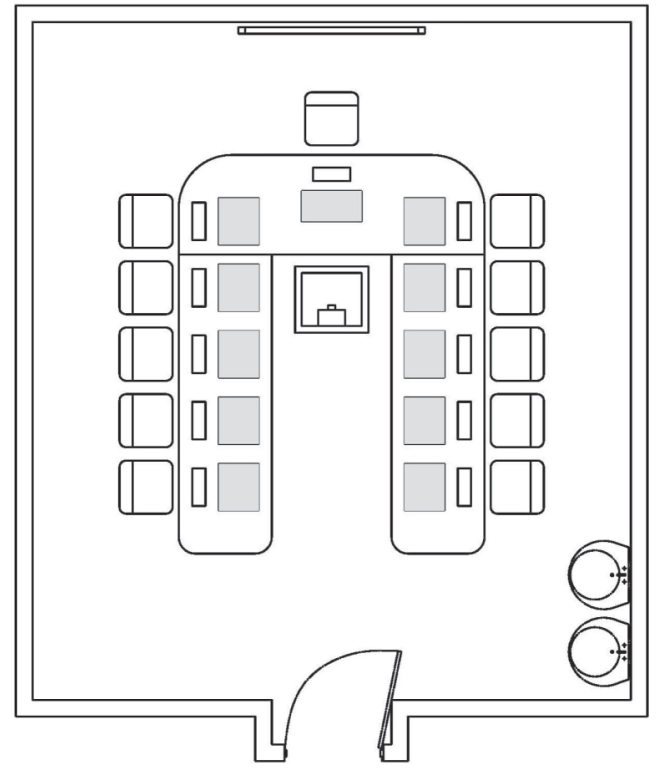

Fig. 2. The scheme of a computer classroom.

16) If we want to achieve a more effective education, we have to also provide optimal working environment and pupils' well-being which would be coherent in all components (visual, acoustic, thermal, air and ergonomic). We recommend implementing the teaching process and teaching with MTA in a training classroom (Fig. 2). To ensure pupils' activities, especially in group work, and cooperative learning, we need to place desks in a position adapted to this kind of work.

It is necessary to have a projection wall area, a demonstration area, an installed central control of teaching techniques in the teacher's desk as well as the imposition of teaching aids in an easily accessible way (Agnew, 1996).

The primary task of schools and teachers, who are planning to implement the teaching process in a computer classroom, is to ensure optimal working environment to be harmonized in all its components. The teaching process cannot negatively affect the healthy physical and mental development of pupils. In order to achieve maximum performance, pupils as well as teachers need to have optimal working environment (a high-quality computer classroom).

\section{Disadvantages of Multimedia Teaching Aid}

Although we believe that the use of MTA in teaching pupils is of a great benefit for the teacher, it is necessary to draw attention to possible barriers that affect the effectiveness of teaching with MTA. Like everything has its pros and cons, MTA brings some disadvantages and limitations too. 


\section{Disadvantages and Limitations Resulting from Computer Literacy}

The teacher and pupils have to be on at least a minimum level of computer knowledge and skills to successfully manage the basic functions associated with the use of teaching software. Success of teaching with MTA is threatened without the necessary skills.

\section{Disadvantages and Limitations Arising from the Competences of the Pupil}

A successful pupil has a good organization of work, can motivate himself or herself, can organize time well and can provide a reasonable work time. For this reason, it would be ideal, if the participants of the education with MTA were pupils who are independent of foreign assistance and with internal motivation. However, it is not very often possible and therefore, the teacher has to give more attention to the pupils.

\section{Disadvantages and Limitations Arising from the Teacher's Competences}

If the teacher does not know the basic traffic rules and if he or she has problems in this issue, there may be mistakes in teaching. Mistakes in the teacher's work and organization of the teaching may be reflected in the loss of interest of pupils.

Disadvantages and Limitations Resulting from Computer Technical Equipment Education with MTA is possible only if schools have computer classroom equipped at least by the basic equipment. This technical equipment is the biggest limitation for the use of the aid.

\section{Disadvantages and Limitations Arising from the Implementation of Teaching in the Training Classroom}

Implementation of the teaching process in the training classroom means that pupils move from one training classroom to another following their timetable. The transition to teaching in the classroom training is carried out efficiently at the same time with the whole class. The most effective is to move to the training classroom with the whole class. The teacher must plan in advance when he or she will implement the teaching process with MTA in the training classroom (England and Finney, 1999).

\section{Research of the Impact of MTA on Development of RSE at Slovak Schools. Subject, Aims and Hypotheses of the Research}

This chapter aims to present the actual results of the research that we gathered in the research of implementation of MTA into teaching. It ought to highlight the merits of using MTA in teaching Road Safety Education. We chose the method of experimental verification for the purposes of this research.

\subsection{Subject of the Research}

The research was made among pupils of the 2nd level of primary school. Teaching of Technical Education in selected thematic areas is supported by MTA that we designed 
for the field of Road Safety Education. There is an optimum support of information and communication technologies.

\subsection{Aims of the Research}

The aim was to verify the success of the use of MTA in real conditions of the selected schools having Technical Education, where work with computers is also used. We examined the knowledge of the first three levels of educational objectives of Niemierko taxonomy and active learning of pupils.

To meet the educational research aims of the dissertation thesis, we set the following sub-tasks:

- to point out by the analysis of pedagogical documentation (curriculum, education standards, textbooks, suprasubjectival curricula for RSE) that teaching of road safety education is needed within Technical Education;

- to design MTA that would be focused on the development of road safety education for pupils of the 6th year within the subject of Technical Education at the 2nd level of primary schools;

- to verify MTA for road safety education for primary schools in the teaching practice;

- to verify our hypotheses by the use of research techniques and methods;

- to find out whether the application of MTA for road safety education affects the level of theoretical knowledge in understanding, remembering, specific transfer and active learning of pupils the 6th year of primary schools in the subject of Technical Education at the 2nd level of primary schools (Stebila, 2008).

A natural educational experiment was performed within the research. Teaching was carried out in experimental classrooms (MTA was used in the teaching process) and control classrooms, where the teaching was carried out in a traditional way without using MTA.

We were especially interested in those educational features which have the highest priority in relation to the creative-humanistic teaching in the theory.

When dealing with the issue of implementing Road Safety Education of pupils at primary schools, the following objective was set within the educational research: To find out whether it is possible to develop cognitive abilities of a pupil from road safety education for pupils of the 6th year of primary schools by the use of the suggested MTA when teaching Technical Education.

\subsection{Research Problem}

In our country, there is no debate on Road Safety Education and convenience of the use of computers to carry out this issue. We are aware of the vastness and complexity of the issue and we know that we can and we should explore it in great detail. It is interesting for us to know if pupils achieve better learning results in the first three areas of Niemierko taxonomy (remembering, understanding, specific transfer) when MTA is used in teaching, 
and if pupils learn more actively in the classroom, where MTA is used in comparison to teaching applying the traditional teaching methods.

We formulated the following principal and starting hypothesis from already expressed research questions:

$\mathrm{H}$ : The use of suggested multimedia teaching aid in teaching of Technical Education on the 2nd level of primary schools will statistically affect the level of pupils' knowledge of road safety education in a significant way.

To be able to confirm or refute and quantitatively and qualitatively verify the main and starting hypothesis, we formulated the following working hypotheses:

H1: When dealing with the tasks of the didactic test focused on the issue of road safety education, pupils from the experimental group will achieve statistically significantly better results in the first three areas of Niemierko taxonomy than pupils from the control group.

H2: Pupils who are taught with MTA will have at the end of the experimental teaching better results in the didactic test in the area of specific transfer than pupils who are taught traditionally.

H3: Pupils who are taught with MTA will have at the end of the experimental teaching better results in the didactic test in the area of understanding than pupils who are taught traditionally.

H4: Pupils from the experimental group, in which MTA is used, will learn more actively during the lessons than pupils in the control group, in which MTA is not used.

\subsection{Research Sample}

The basic set, suitable for our research, were pupils of the 6th year of the 2nd level of primary schools in the Slovak Republic. We can consider the results of the population of pupils of the 6th year in the Slovak Republic to be normally distributed. That is why we can process data as a selection of the normal distribution in the research. In terms of external validity of the research, we performed the sampling selection by the stratified selection. The sample was made of 214 pupils of the 6th year from five primary schools in the Slovak Republic. To be able to objectively determine whether our MTA (independent variable) affects the level of knowledge of road safety education of pupils of the 6th year of primary schools in Technical Education, we included two groups of respondents in the experiment: the control group and the experimental group. The control and experimental groups were always formed by the entire class. The control group consisted of 107 pupils. 107 pupils were also in the experimental group. Table 7 shows the various numbers in the sets of different schools. We purposefully marked all control subgroups as one control group CON and all the experimental subgroups are identified as one experimental group EXP.

\subsection{Performance of the Experiment}

We started the experiment at primary schools in both groups simultaneously at the beginning of February 2007. Both groups followed the same schedule and content. The only 
difference in the teaching of both experimental and control groups (EXP, CON) was the application of the verified MTA. This teaching aid was used only in the experimental group, while in the control group the teaching was conducted in a standard way, without the use of this multimedia teaching aid.

During the performance of the experiment, pupils did not know that they are in the experimental group. Thus we were able to ensure the confidentiality against undesirable external influences, and we prevent a formation of intervening variable.

In the way of the above described selection procedure, we developed an assumption to a valid determination of the impact of the experimental operation whereas the intervening variables remained constant during the experiment. The selection procedure, however, could not affect certain effects that could distort research results. Among such effects we include the impact of gender, family ownership of a computer, intelligence, previous experience, etc. Their potential impacts on the results of the research are also considered to be constant.

Each pupil was informed that he or she would have to take an obligatory didactic final test, which could not be possible to implement in an alternative day. We believe that due to this requirement, the participation in the final didactic test was of $100 \%$.

The final didactic test was carried out after the thematic unit of Road Safety Education named Machines and Mechanisms. Both groups were tested in their school. All pupils had equal working conditions and the same instructions. The final didactic test for each student consisted of 18 questions. We chose them from the bank of tasks after the agreement with teachers. Pupils had to give or choose the answers. The questions were identical for all pupils. The tests differed only in sequence. Their contents were same. To reduce and minimize cheating, we had made two variations of the final didactic test. The time limit for the test was 22 minutes. After this time limit, it was not possible to complete the test. Blank questions were evaluated as false, i.e. 0 points. A pupil could get a maximum of 33 points for the whole test, while for each correctly answered question there were 1,2 or 3 points.

After completing the test, an anonymous completing of questionnaires took place. The standardized questionnaire AUS was distributed to pupils. It diagnoses the active learning of pupils during lessons from their answers on teaching of a certain subject. The administration of the questionnaire takes approximately 10 minutes. Total score of the questionnaire is corresponding to the processes of active learning, which is diagnosed in the questionnaire in five areas:

- PLACE of learning (at home, at school);

- FREQUENCY of situations in which active learning of pupils takes place during a lesson;

- TIME of active learning during a lesson;

- FORM of active learning of pupils during a lesson;

- FEEDBACK on learning.

We considered the inclusion of the standardized questionnaire for a long time, but finally we used it for measuring. However, we think that the more appropriate method for diagnosing this problem would be the method of observation and dialogic methods. 
The pedagogic experiment took place during lessons in several schools of Slovak towns. For that reason, we could not play the role of the observer.

Filling in the questionnaire took place in the classrooms, which have a classic in-line arrangement of desks. Pupils were sitting in the way they could not cheat.

During the performance of the pedagogic experiment we did not mark any significant effects that could undermine the measured results and the main objective of the research. After the teaching experiment, we collected the obtained data and subjected them to statistical and qualitative analysis.

\section{Statistical Processing and Analysis of the Collected Data}

A standardized questionnaire AUS was used for determined the degree of active learning of pupils. The results of the measurements of the variable ACT were analyzed by the methods of descriptive statistics. The results are comprehensively shown in the following tables and graphs.

Values which are processed in table and Fig. 3 show the differences in the degree of active learning of pupils during lessons of Technical Education when MTA was used in the experimental and control groups.

Figure 3 shows that pupils reflected the degree of active learning in a different way. Pupils perceived a very good degree active learning during lessons in the experimental group. The measured median value shows that the teacher using MTA created favorable conditions for active learning of the pupils. The teacher regularly prepared appropriate learning tasks and activities with the feedback of learning. Pupils were active during

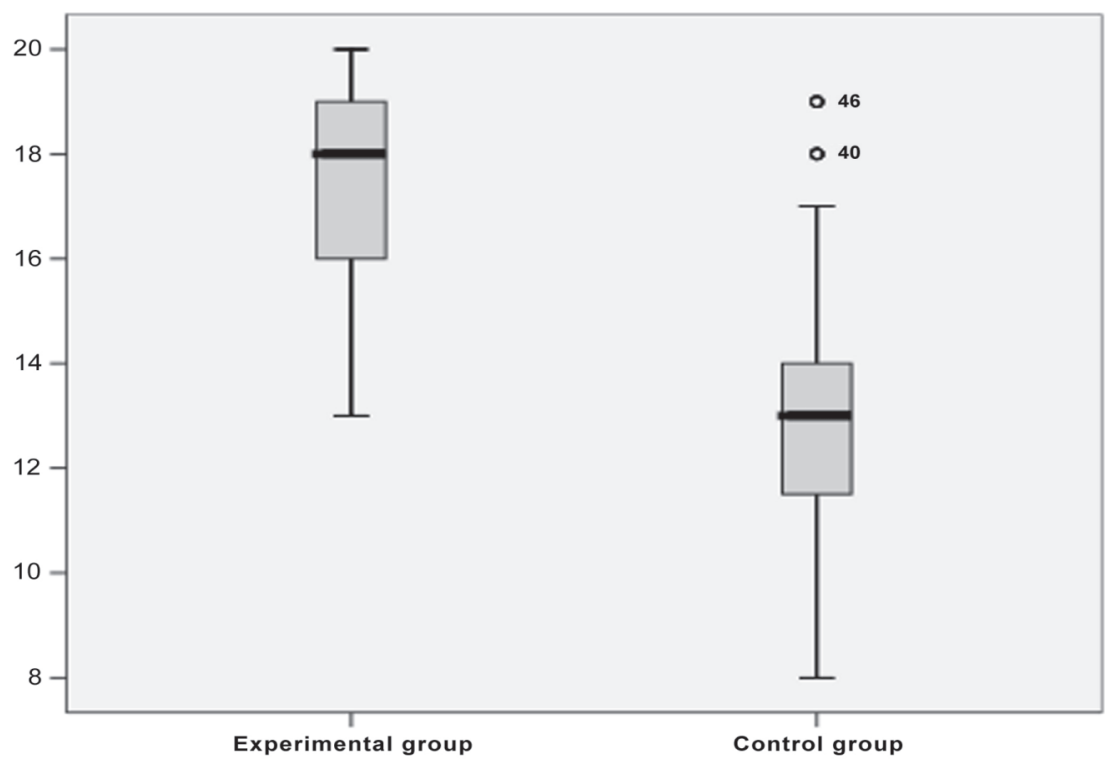

Fig. 3. The box plot for hypothesis H. 
the lessons, they learned the subject matter mostly in school and consequently, they did not need to learn at home.

Lower degree of active learning during the lessons was perceived by pupils in the control group. The measured median values indicate that the teacher using methods and teaching aids (other than MTA) did not create very favorable conditions for active learning during the lessons. Pupils could collaborate in groups during the lessons, but the active learning with a feedback of a good quality, due to lack of time, was rare. The activity during the lesson was mostly performed by the teacher. Pupils were rather passive, as observers, during the lessons.

These research results show us the differences in the degree of learning during lessons of pupils from the experimental and control groups. The assumption of the research on the differences in the degree of active learning of pupils in the classroom turned out to be true and confirmed for the sample. The subsequent inductive methods confirmed that assumptions on the differences of the degree of active learning of pupils are applied with the probability of $95 \%$.

It is clear from the frequency Tables 1, 2, and then the generated histogram (Fig. 4) compared with a curve of normal distribution, that the data are not normally distributed as confirmed by the QQ plot (Fig. 5).

Pupils from the control and experimental groups achieved in the research different scores and they were placed in a variety of qualitative intervals within the different scales. In order to generalize the argument as a basic set, we performed an inductive statistical analyze. Based on the analysis of the characteristics of both groups (CON, EXP) we can confirm that it is reasonable to test the hypothesis $\mathrm{H}$ which says that pupils who are taught with MTA will learn during the lessons more actively than pupils who are taught traditionally without using MTA. This means that we will test the hypothesis:

H0: Median value (estimated by the arithmetical average) of experimental and control group is the same.

Table 1

The frequency table for the experimental group $\mathrm{H}$

\begin{tabular}{lcccc}
\hline Points & $\begin{array}{l}\text { Frequency } \\
\text { Percentage }\end{array}$ & Expected & $\begin{array}{l}\text { Percentage } \\
\text { Frequency } \%\end{array}$ & Cumulative \\
\hline 13.00 & 5 & 4.7 & 4.7 & 4.7 \\
14.00 & 5 & 4.7 & 4.7 & 9.3 \\
15.00 & 8 & 7.5 & 7.5 & 16.8 \\
16.00 & 12 & 11.2 & 11.2 & 28.0 \\
17.00 & 18 & 16.8 & 16.8 & 44.9 \\
18.00 & 24 & 22.4 & 22.4 & 67.3 \\
19.00 & 28 & 26.2 & 26.2 & 93.5 \\
20.00 & 7 & 6.5 & 6.5 & 100.0 \\
Total & 107 & 100.0 & 100.0 & \\
\hline
\end{tabular}


Table 2

The frequency table for the control group $\mathrm{H}$

\begin{tabular}{rcccc}
\hline Points & Frequency & $\begin{array}{l}\text { Expected } \\
\text { Percentage }\end{array}$ & Percentage & $\begin{array}{l}\text { Cumulative } \\
\text { Frequency \% }\end{array}$ \\
\hline 8.00 & 2 & 1.9 & 1.9 & 1.9 \\
9.00 & 6 & 5.6 & 5.6 & 7.5 \\
10.00 & 7 & 6.5 & 6.5 & 14.0 \\
11.00 & 12 & 11.2 & 11.2 & 25.2 \\
12.00 & 23 & 21.5 & 21.5 & 46.7 \\
13.00 & 21 & 19.6 & 19.6 & 66.4 \\
14.00 & 10 & 9.3 & 9.3 & 75.7 \\
15.00 & 10 & 9.3 & 9.3 & 85.0 \\
16.00 & 4 & 3.7 & 3.7 & 88.8 \\
Total & 107 & 100.0 & 100.0 & \\
\hline
\end{tabular}
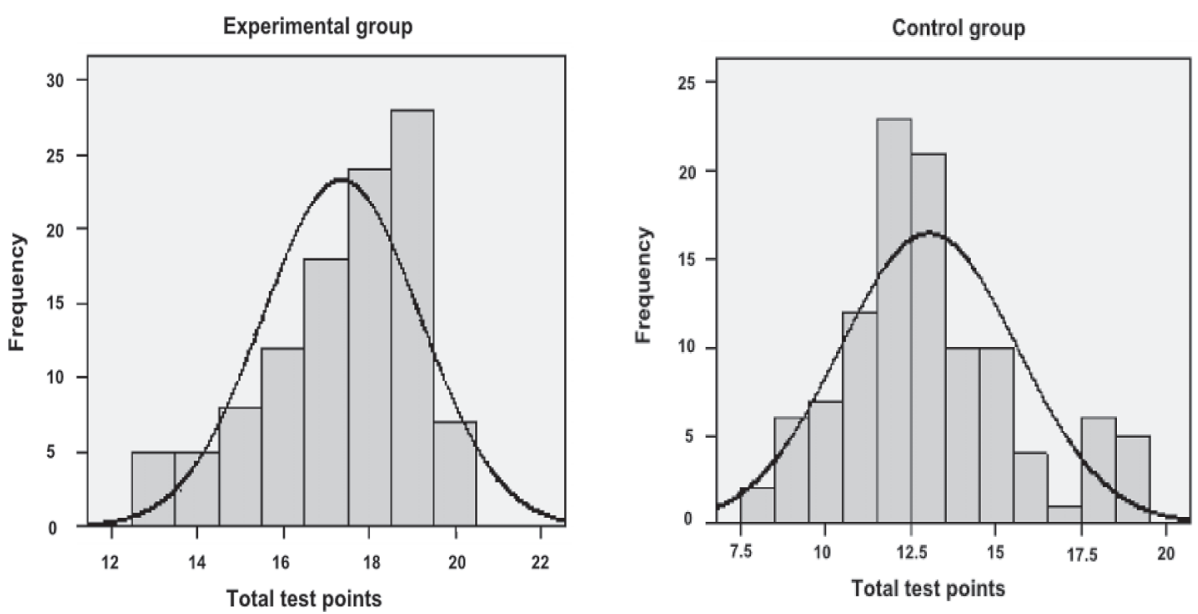

Fig. 4. The histogram of the frequency of the variable ACT in experimental and control groups.

The implemented Leven F-test unambiguously declares that we reject the hypothesis $\mathrm{H} 0$ of equal scatters $(p=0.017<0.05)$. Because of this, we take into account the results from the bottom line (the output of the statistical system SPSS for two-sided alternative, where $p$ (T-test) $=0.061$ and $p$ (T-test) $=0.008$ (for two-sided alternative), thus we reject the hypothesis H0. We summarily show the outputs from the system SPSS of the T-test in the Table 3.

Statistical testing by using the T-test confirmed the significance of differences in the performance of experimental group and control group, which is caused by the use of MTA.

The results show that MTA affects the active learning of pupils. The measured value confirmed the test of the hypothesis on the significance of differences of the arithmetical averages of the score of the dependent variable ACT (Table 3). 

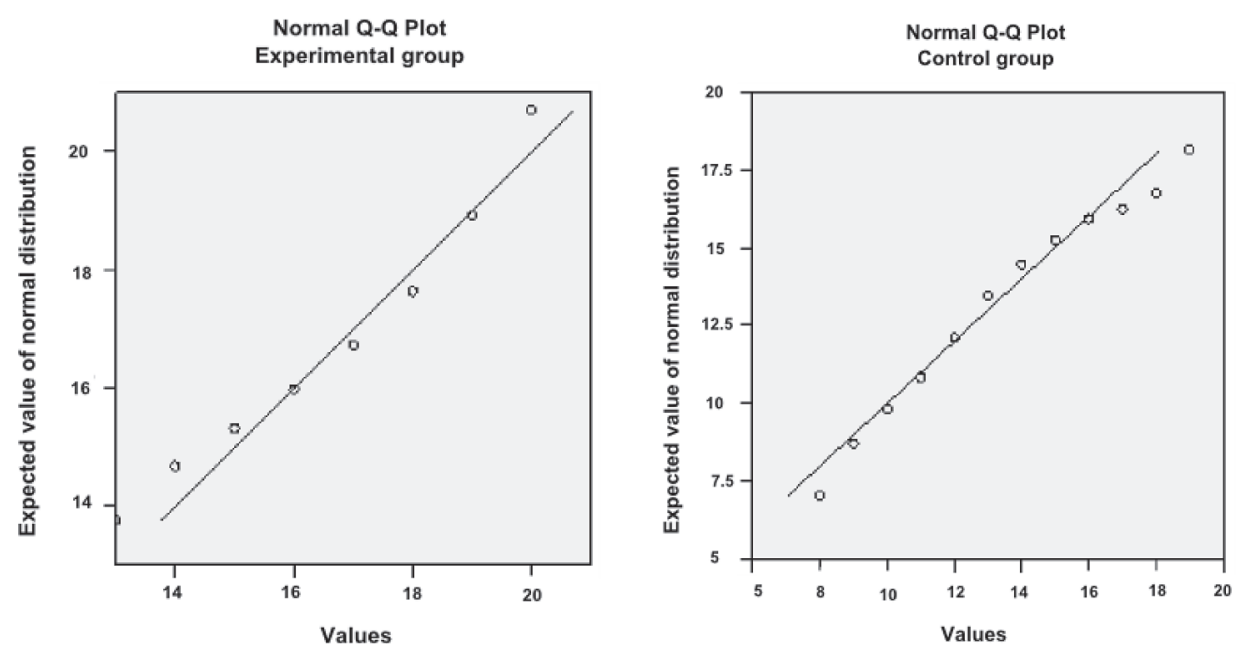

Fig. 5. The Approximation of the Distribution of the Variable ACT Frequency to a Normal Distribution.

Table 3

The T-test with two choices on the equality of the median values for hypothesis $\mathrm{H}$

\begin{tabular}{|c|c|c|c|c|c|c|c|c|c|}
\hline & \multicolumn{2}{|c|}{ Leven F-test } & \multicolumn{4}{|c|}{ T-test on the equality of the median values } & \multirow{3}{*}{$\begin{array}{l}\text { Standard } \\
\text { error of the } \\
\text { difference } \\
\text { of median } \\
\text { values }\end{array}$} & \multirow{2}{*}{\multicolumn{2}{|c|}{$\begin{array}{l}95 \% \text { konf. } \\
\text { interval for } \\
\text { the scatter }\end{array}$}} \\
\hline & $\mathrm{F}$ & $\begin{array}{l}\text { P-value } \\
\text { of } \\
\text { F-test }\end{array}$ & $\mathrm{T}$ & df & $\begin{array}{l}\text { P-value } \\
\text { two-sided } \\
\text { alternative }\end{array}$ & $\begin{array}{l}\text { Difference } \\
\text { of median } \\
\text { values }\end{array}$ & & & \\
\hline & & & & & & & & Down & Upper \\
\hline $\begin{array}{l}\text { Equality } \\
\text { of scatters }\end{array}$ & 5.749 & 0.017 & 14.082 & 212 & 0.000 & 4.31776 & 0.3066 & 3.7133 & 4.9222 \\
\hline $\begin{array}{l}\text { Inequality } \\
\text { of scatters }\end{array}$ & & & 14.082 & 190.596 & 0.000 & 4.31776 & 0.3066 & 3.7129 & 4.9226 \\
\hline
\end{tabular}

The T-test confirmed that the difference of averages of the total score from the standardized questionnaire AUS of the dependent variable ACT was not random, but it was significant on the level of significance 0.05 .

Based on the facts, we can state that if the teacher taught with the same MTA in the control group as he or she had taught in the experimental group, then pupils would reflect, with greater probability than $95 \%$, the degree of the active learning during lessons in the same way and as pupils from the experimental group.

The research results confirm the assumptions made in the working hypothesis $\mathrm{H}$. We argued that pupils from the experimental group, where MTA is used, will learn more actively during the lessons than pupils from the control group, where teacher does not use this MTA. 
The hypothesis was confirmed, and its validity can be generalized to a basic set of pupils who took part in the research.

\section{Evaluation of the Research and Prediction of the Application of MTA in Teaching}

The purpose and the main aim of the pedagogic experiment were to practically verify the success of MTA in conditions of primary schools. We assumed that the use of our multimedia teaching aid in teaching Technical Education on the 2nd level of primary schools would significantly affect the level of knowledge of pupils from the issue of road safety education, particularly in terms of performing, remembering, understanding, specific transfer and active learning of pupils.

The validity of the working hypotheses on the level of significance 0.05 is shown in Table 4. We used a non-parametrical test on the compatibility of median values for verifying the main hypothesis.

It is possible to say that from the statistical analyses and conclusions of testing partial hypotheses, the initial hypothesis is confirmed and true on the chosen level of significance 0.05 and in the given conditions. The research on the application of the presented MTA and its methodology on the level of significance 0.05 allow us to state that:

- Pupils who were taught with MTA achieved at the end of the experimental teaching a better performance in the didactic test in the area of specific transfer, understanding and remembering than pupils who were taught traditionally.

- Pupils who were taught with MTA learnt more actively during the lessons than pupils who were taught traditionally.

\section{Conclusion}

Teaching by using MTA requires an intensive work with modern technologies at the beginning and it is connected with a certain risk that is always present when using computer techniques. Working with the aid gives much more pleasure from teaching and learning.

Table 4

The summary of the verification of the hypotheses

\begin{tabular}{llll}
\hline Hypothesis & $\begin{array}{l}\text { Method for } \\
\text { obtaining the facts }\end{array}$ & $\begin{array}{l}\text { Validity of the } \\
\text { hypothesis }\end{array}$ & Examined variable \\
\hline H1 & DT - final & valid & performance in the cognitive area \\
H2 & DT - final & valid & $\begin{array}{l}\text { specific Transfer } \\
\text { understanding } \\
\text { H3 }\end{array}$ \\
H4 & DT - final & valid & active learning \\
& standardized & valid & \\
\hline
\end{tabular}


Moreover, the total effectiveness of the learning surpasses traditional forms of education in the subject when using the aid in a right way. MTA designed in this way gives a chance for a greater discussion among pupils in the classroom, teachers and pupils, teachers of Technical Education and teachers of different subjects.

We are convinced that MTA fully uses the potential of actual modern information and telecommunication technologies. The teaching aid integrates actual principles of creative and academic education. When we use it in the right way, it can make the process of education significantly simpler and more effective. It helps to satisfy the needs of pupils in the cognitive but also in the affective area that have a key importance in the education of the youth in the long-term point of view.

Information from the experiment but also our experience of using the teaching aid enable us to suggest that MTA has a great chance to become a standard in education with computers in the future. The teaching aid of this kind of education has not been elaborated by this time. We hope that this aid will help to standardize the tool in the field of education.

We would like to continue in the pending research in the future. We focus on the possibility of application of MTA in the educational process not only within Technical Education but also in the subjects where the issue of RSE is included in the content of the subjects at schools of different Slovak regions.

If we try to find a common denominator of the following chapters, then it is our desire to promote the issue of Road Safety Education at Slovak primary schools, whose quality is to be a guaranteed and functioning system. A creation and implementation of modern multimedia teaching aids give a good opportunity to it. It depends on people (teachers) who create and implement it together. In case of Road Safety Education, there is no doubt that the effort is worthwhile.

It is known that education is developing dynamically and multimedia entered also this issue. On the other hand, there are relatively few comparative materials dealing with real, practical experience and examples of teaching of Road Safety Education in different countries.

\section{References}

Alessi, S.M., Trolltip, S.R. (2001). Multimedia for Learning. Boston.

Agnew, P. W. (1996). Multimedia in the classroom. Allyn and Bacon, Massachusetts.

England, E., Finney, A. (1999). Managing Multimedia, Project Management for Interactive. Medi, AddisonWesley.

Hillman, D. (1998). Multimedia Technology and Applications, Delmar Publishers.

Hockicko, P. (2010). Nontraditional approach to studying science and technology. Communications, 12(3), 66-71.

Mc Mahon, K. (2004). Keeping Children Safe in Traffic. Brussels.

Kmet'ová, J. (2006). Modernization of educational content in Slovak basic and secondary schools. In: Badania w dydaktyce chemii Krakow, AP, 191-196.

Krišt'ák, L., Gajtanska, M. (2010). Teaching innovations in the chosen fields of Physics. Problemy Profesjologii, 2, 195-201.

Krišt'ák, L, Němec, M. (2010). tInnovation of physical education at Technical university in Zvolen. Journal of Technology and Information Education, 2, 40-45. 
Kučerka, M. (2009). Legislative in the sphere of safety and health protection at work and education. Acta Universitatis Matthiae Belii, 9, 24-30.

Stebila, J. (2009). Results of the research of using the multimedia teaching aid under real conditions at primary schools in SVK. JTIE, 1(1), 49

Stebila, J. (2008). Incorporating the Problems of the Road Safety Education into the Curriculum of the Technical Education at the Secondary Level of the Elementary Schools. Dissertation thesis. Matej Bel University, Faculty of Natural Sciences, Department of Technology, 49-54.

Stebila, J. (2010). New Forms of natural sciences education in the context of lower secondary education in the Slovak republic. Communications, 12(3), 48-53.

Traffic Safety Education at the Secondary School Level in the EU Countries. (1996). Europen Study, Brussels European Road Safety Federation.

Žáčok, L. (2010). Research examination of the options to increase the education effectiveness in the technical subjects at the 7th grade of elementary school using hypertext educational material. Informatics in Education, 9(2), 283-299.

J. Stebila, Dr., PhD. The author is currently working as a lecturer at the University of Matej Bel, Faculty of Natural Science, Department of Techniques and Technologies. He publishes scientific and technical contributions at home and abroad. He is co-author of scientific monograph called „School for Road Safety - Polosh Slovakian Comparative Study“ which was published on Zielonogórska University in Poland. Scientific research: research on the inclusion of traffic education in to content of the school subject technology, use of IKT in technical subjects, theory and teaching technical subjects.

\section{Daugialypès mokomosios priemonès taikymo techniniam lavinimui pradiniu mokyklu aukštesnèse klasèse tyrimas ir prognozès}

\section{Ján STEBILA}

Autoriaus pedagoginio eksperimento svarbiausias tikslas buvo ịvertinti daugialypès mokomosios priemonės naudojimo pradinėse mokyklose sékmę. Straipsnio autorius mano, kad šiu priemonių naudojimas techniniam mokymui žymiai paveiks mokinių žiniu lygị. Pateikiamas lavinimo keliụ eismo saugumo srityje pavyzdys, nagrinejama, kaip mokiniai atlieka užduotis, isimena, supranta, aktyviai mokosi. 